УДК 37.015.311

DOI: https://doi.org/10.31470/2518-7600-2020-10-310-333

FORMATION OF INFORMATION CULTURE OF THE FUTURE SPECIALIST IN THE CONTEXT OF MODERN EDUCATIONAL TASKS

\title{
ФОРМУВАННЯ ІНФОРМАЦЙНОЇ КУЛЬТУРИ МАЙБУТНЬОГО ФАХІВЦЯ У КОНТЕКСТІ СУЧАСНИХ ОСВІТНІХ ЗАВДАНЬ
}

\section{ФОРМИРОВАНИЕ ИНФОРМАЦИОННОЙ КУЛЬТУРЫ БУДУЩЕГО СПЕЦИАЛИСТА В КОНТЕКСТЕ СОВРЕМЕННЫХ ОБРАЗОВАТЕЛЬНЫХ ЗАДАЧ}

\section{Олена Коломісць,}

кандидат педагогічних наук, доцент кафедри суспільних наук, інформаційної та архівної справи, kolomietselena1964@gmail.com arhival affair ORCID: 0000-0003-0085-7605 Центральноукраїнський національний технічний університет, пр.-т Університеський,8, м. Кропивницький, Кіровоградська обл., Україна, 25006

\section{Оксана Головата,}

викладач кафедри суспільних наук, інформаційної та архівної справи o.o.golovata@gmail.com
Olena Kolomiiets, candidate of pedagogical sciences, associate professor of the department of public sciences, information and kolomietselena1964@gmail.co $\mathrm{m}$

ORCID: 0000-0003-0085-7605

Central-Ukrainian National Technical University, Universytetskyi Prospect, 8, Kropyvnytskyi, Ukraine, 25006

\section{Oksana Holovata,} vykladach of the department of public sciences, information and arhival affair

o.o.golovata@gmail.com 
ORCID: 0000-0003-2232-819X

Центральноукраїнський

національний технічний

університет

пр.-т Університетський, 8

м. Кропивницький,

Україна, 25006
ORCID: 0000-0003-2232-819X

Central-Ukrainian National

Technical University,

Universytetskyi Prospect, 8,

Kropyvnytskyi, Ukraine, 25006

\section{ABSTRACT}

The publication is devoted to the problem of formation of information culture of the future specialist of the information sphere.

The concept of «information culture», the prerequisites for the emergence of information culture in society, its main components and levels of functioning are considered.

Information culture is considered as a way of human life in the information society, an integral part of the process of the culture of mankind formation, as a culture of man, ready for creative work in the conditions of technological and information system of society development.

This definition of information culture allows you to consider the main problems and trends systematicallyin the development of information culture, to identify the object and subject of its studyadequately, as well as to structure its subject area.

The information culture of the person which is a condition of successful adaptation of the person to a life in the information society making a general culture focused on information maintenance of human activity is analyzed.

The formation of information culture of the future specialist in the information sphere is presented as a complex process, including educational resources of the general culture of society, the potential of educational and socio-cultural environment of higher education, spiritual self-development of the student. It is emphasized that the formation of information culture only through the study of computer science is insufficient, as it limits this process to technical and software means of informatization. 
The expediency of including special training courses in the educational process, in particular, "Fundamentals of information culture» or "Information culture of the future specialist» is substantiated.

The characteristic of organizational and pedagogical conditions of successful implementation of process of formation of information culture of the future expert is given. The importance of active use of information technology tools is emphasized.

The conclusion emphasizes the search for effective innovative models for the training of information professionals capable of integrated activities aimed at the creation and use of information resources and the creation of information products, Providing information services, information support and support for all activities. Perspective directions in further research of this problem are defined.

Keywords: information, information society, informatization, information culture, information technologies, information sphere specialist.

Постановка проблеми. В умовах інноваційних перетворень сьогодення значення інформації в житті людей постійно зростає. Визначною рисою сучасної епохи $\epsilon$ інформатизація всіх галузей людської діяльності. Інформаційні ресурси розглядаються як багатство, що не поступається за своїм значенням і потенційним ефектом природним ресурсам.

Процес накопичення інформації та знань, які фіксуються в документах, домінування інформаційно-комунікаційних технологій у суспільно-економічних відносинах, створення глобального інформаційного простору наклали відбиток і на систему вищої освіти, поставивши нові вимоги до організації та якості підготовки майбутніх фахівців. Це стосується, зокрема, розширення масштабів освітньої діяльності, необхідності підняття системи освіти до рівня потреб науки і суспільної практики, перетворення ії̈ на важливий компонент культури, в межах якого відбувалася б передача і засвоєння соціокультурного досвіду і знань. 
Тому важливими завданнями освіти на сучасному етапі $€$ підготовка молоді до швидкого сприйняття й опрацювання великих обсягів інформації, озброєння новітніми засобами та технологіями діяльності, формування інформаційної культури, як базової характеристики, що визначає рівень інформаційного мислення та професійної мобільності особистості. Особливу роль інформаційна культура має відігравати у професійній підготовці майбутніх фахівців інформаційної сфери.

Актуальність досліджуваної теми обумовлюється, таким чином, пошуком нових сучасних підходів до організації системи професійної підготовки майбутнього інформаційника, духовного розвитку особистості в умовах інформатизації суспільства. Це вимагає набуття вмінь здійснювати пошук, обробку, оцінку й систематизацію великої кількості інформації та знань, а також зумовлює важливість застосування особистісно-орієнтованого підходу до розвитку критичного мислення студентів, всебічного аналізу отриманої інформації.

Аналіз останніх досліджень і публікацій. Ця проблематика знайшла відображення в працях вітчизняних та зарубіжних авторів: В. Бездрабко (Бездрабко, 2009) Н. Гендіної (Гендіна, 1999), М. Левшина (Левшин, 2002), Л. Філіпової (Філіпова, 2008, 2003). Протягом останніх років активно ведуться дослідження з проблем інформаційної, інформаційнокомунікативної компетентності майбутнього фахівця, зокрема у працях М. Антонченко (Антонченко, 2004), Н. Баловсяк (Баловсяк, 2004), О. Барми (Барма, 2014), Г. Власової (Власова, 2002), Л. Філіпової (Філіпова, 2011). Вивченню міжнародного досвіду професійної підготовки фахівців документноінформаційної сфери присвячені наукові праці I. Антоненко (Антоненко, 2006), С. Кулешова (Кулешов, 2003), О. Матвієнко (Матвієнко, 2001).

Аналіз наукових напрацювань вітчизняних та зарубіжних дослідників дозволяє стверджувати, що проблема формування інформаційної культури має багатоплановий та багатоаспектний характер. Це обумовило наявність великої 
кількості наукових праць, присвячених піi розробці. Проте багато важливих аспектів проблеми формування інформаційної культури ще не знайшли свого наукового розв'язання. Подальшої розробки потребують питання, пов’язані 3 обгрунтуванням організаційно-методичних основ формування інформаційної культури особистості у контексті сучасних освітніх завдань, визначенням педагогічних умов формування інформаційної культури фахівця, вивченням досвіду формування інформаційної культури майбутніх фахівців інформаційної сфери.

Мета статті - визначення на основі аналізу поняття «інформаційна культура» та узагальнення досвіду підготовки фахівців у закладах вищої освіти можливих шляхів формування інформаційної культури майбутніх фахівців інформаційної сфери, виявлення відповідних педагогічних умов та особливостей цього процесу.

Виклад основного матеріалу. Формування інформаційної культури у нинішнього покоління людей $є$ соціальним замовленням інформаційного суспільства, перехід до якого почався 3 другої половини XX ст.. Це століття визначило головним ресурсом інформацію, а основними технологіями - інформаційні технології пошуку, подання, обробки, збереження та використання інформації.

Передумовами виникнення інформаційної культури $є$ перехід інформації до розряду найважливіших універсальних категорій суспільного розвитку, стрімке зростання обсягів інформації, становлення інформаційного суспільства, розвиток інформаційної техніки та інформаційних технологій. У свою чергу, інформаційна культура стала певною умовою успішної адаптації людини до життя в інформаційному суспільстві.

Термін «інформаційна культура» у вітчизняних публікаціях вперше з'явився в 70-х рр. минулого століття. Ініціаторами привернення уваги громадськості до цього феномену стали робітники бібліотек. 
3 кінця 1980-х рр. проблемами інформаційної культури зацікавились також суспільствознавці, філософи, фахівці в галузі філософії інформації, визнавши їі важливим компонентом духовної культури суспільства й окремих особистостей.

3 часом поняття інформаційної культури вбирало в себе знання тих наук, які стали основою для реалізації принципово нових підходів до роботи з інформацією. Особливий вплив на наповнення поняття інформаційної культури новим змістом справили роботи фахівців у галузі інформатики, обчислювальної техніки, новітніх інформаційних технологій.

У процесі розвитку інформаційної культури до кола тих фахівців, хто бере участь в іï формуванні, стали входити представники таких наук, як семіотика, лінгвістика, соціологія, психологія, педагогіка, культурологія, естетика тощо. Поступово почала утверджуватися точка зору про необхідність узагальнення накопичених знань 3 теорії інформаційної культури в рамках інформаційної культурології, теоретичне осмислення якої було закладене в працях М. Вохришевої (Вохришева, 1994, 1997).

Нині є всі підстави говорити про формування нової інформаційної культури як системи певних компонентів, зокрема: культури організації подання інформації, культури сприймання та користування інформацією, культури використання нових інформаційних технологій, культури спілкування через засоби нових інформаційних технологій.

Інформаційна культура органічно входить до реалій суспільного життя, додаючи йому нової якості. Вона призводить до зміни багатьох економічних, соціальних, політичних і духовних уявлень людей.

Об’єктами інформаційної культури є інформаційні процеси та існуючі інформаційні відносини в суспільстві; а також система знань, умінь і навичок у роботі з інформацією. Залежно від суб’єкта, який виступає носієм інформаційної культури, виділяють три їі рівні: 
- інформаційну культуру особистості як одну із складових загальної культури людини, систему знань і умінь, що забезпечують цілеспрямовану самостійну діяльність індивіда щодо задоволення інформаційних потреб із використанням традиційних джерел інформації і новітніх інформаційних технологій;

- інформаційну культуру окремих груп і спільнот, яка характеризує рівні розвитку конкретних суспільств, націй, народностей, верств, груп за тими чи іншими ознаками;

- інформаційну культуру суспільства в цілому, що характеризує ступінь досконалості соціуму в усіх можливих видах роботи з інформацією.

Що стосується терміну «інформаційна культура особистості», то він був уведений для відображення того факту, що кожна людина повинна мати визначений рівень культури щодо поводження з інформацією.

У наукових розвідках зустрічаємо багато визначень інформаційної культури особистості, зокрема, іiї трактують як:

- рівень знань, що дає можливість людині вільно орієнтуватися в інформаційному просторі, брати участь у його формуванні та сприяти інформаційній взаємодії в суспільстві (Медведєва, 1994);

- галузь культури, пов'язану із функціонуванням інформації в суспільстві і формуванням інформаційних якостей особистості (Вохришева, 1997);

- одну із складових загальнолюдської культури, що включає сукупність інформаційного світогляду та системи знань і вмінь, які забезпечують спрямованість на оптимальне задоволення індивідуальних інформаційних потреб із використанням традиційних i новітніх інформаційних технологій (Гендіна);

- гармонізацію внутрішнього світу особистості під час засвоєння всього обсягу соціально-значущої інформації (Зінов’ єва, 1996) тощо. 
Отже, інформаційна культура представляє собою нову ідеологію і світогляд, у контексті якого формується сукупність ідей і поглядів сучасної молоді, вона виступає ефективним фактором в освоєнні людиною сучасної реальності, оволодінні всім тим багатством, яке виробило людство, атрибутом особистісних проявів у різних способах комунікації. Критеріями інформаційної культури особистості слід вважати iii вміння адекватно формулювати свої потреби в інформації, ефективно здійснювати пошук необхідної інформації, переробляти і створювати якісно нову інформацію.

Крім того, існує безліч близьких до поняття «інформаційна культура», але не тотожних йому за змістом понять: «бібліотечно-бібліографічна культура», «інформаційна грамотність», «комп’ютерна грамотність», «пропаганда бібліотечно-бібліографічних та інформаційних знань» тощо.

Ми будемо дотримуватися визначення інформаційної культури, запропонованого Е. Семенюком: «Інформаційна культура - це інформаційна компонента людської культури в цілому, яка об'єктивно характеризує рівень всіх інформаційних процесів, що існують в суспільстві, та існуючих інформаційних стосунків» (Семенюк, 1994:3).

Сучасна інформаційна культура характеризується збільшенням кількості інформаційно-електронних взаємодій на одиницю часу, здійснюючись за рахунок Інтернету та мультимедійних технологій. Поступово, по мірі розповсюдження технічних засобів і технологічних програм управління обміном інформації все більше актуалізується проблема ïi доступності та збитковості в інформаційному суспільстві. У першому випадку на вирішення проблеми впливають фактори, що залежать від простої наявності технічно опосередкованих носіїв даних та їх якостей. У другому - людину ставлять у залежність від власної технологічної і культурної компетентності, що допомагає вибрати з усього існуючого спектру найбільш адекватні методи отримання та інтерпретації інформації. Така віртуальна 
комунікація істотно змінює темпи духовно-культурного життя суспільства, піддає певним змінам культурний світ людини. Так, зокрема, програми комп'ютерного перекладу сприяють подоланню мовного бар'єру, комп'ютерні мультимедійні енциклопедії і словники розширюють кругозір, відкривають нові методи обробки й аналізу значних за обсягом i різноманітністю змісту інформаційних масивів.

Основне навантаження 3 формування інформаційної культури особистості покладається на систему неперервної освіти, усі складові якої вже випробовують вплив інформатизації суспільства. Суспільство потребує фахівців, які відповідали би європейському та світовому рівню компетентності учасників ринку праці. Крім того, для закладів вищої освіти соціальним замовленням інформаційного суспільства слід вважати забезпечення належного рівня інформаційної культури студента, необхідного для конкретної професійної діяльності. Це стосується зокрема й майбутніх фахівців інформаційної сфери.

Вважаємо, що процес формування інформаційної культури майбутнього інформаційника має включати як освітні ресурси загальної культури суспільства, так і потенціал навчально-виховного і соціокультурного середовища закладу вищої освіти, а також духовний саморозвиток особистості студента. При цьому зазначимо, що формування інформаційної культури тільки через вивчення інформатики виявляється недостатнім, оскільки обмежує цей процес технічними та програмними засобами інформатизації.

Тому система педагогічних заходів, необхідних для забезпечення результативності даної роботи має передбачати: оновлення навчальних планів підготовки бакалаврів і магістрів, зокрема, за спеціальністю 029 «ннформаційна, бібліотечна та архівна справа», синтез досягнень цілого ряду навчальних дисциплін, які вивчають феномен інформаційної культури (інформатики, бібліотекознавства, бібліографознавства, документної лінгвістики, стилістики тексту, теорії соціальних 
комунікацій, логіки, прикладної психології та ін.), доцільність впровадження в навчальний процес спеціальних навчальних курсів, наприклад, «Основи інформаційної культури особистості» або «Інформаційна культура майбутнього фахівця». Головна мета означених курсів мала $б$ полягати у формуванні інформаційного світогляду особистості, підготовці молодої людини до успішного здійснення пізнавальної діяльності, успішної самореалізації в умовах інформатизації суспільства.

Формування інформаційної культури майбутніх фахівців інформаційної сфери доцільно було б починати з:

- формування тезауруса, тобто системи інформаційних понять, що забезпечують загальне і спеціальне орієнтування особистості в інформаційному середовищі;

- обгрунтування загальнометодологічних принципів та умов організації інформаційної освіти.

Базовими поняттями, що забезпечують орієнтування особистості в навколишньому інформаційному середовищі, $є$ наступні: «інформація», «інформаційні ресурси», «інформаційний простір», «інформаційне середовище», «інформаційні потреби», «культура», «інформаційна культура», «інформаційні технології». В процесі навчання студенти осмислюють і узагальнюють ці поняття, звертаючи увагу на їх застосування в майбутній професійній діяльності. Для майбутніх інформаційників важливе значення мають також поняття «документ», «документна інформація», «документні ресурси», «інформаційні потоки», «бібліографування документа», «індексування документа», «анотування документа», «реферування документа» тощо. Таким чином, розуміння сутності понять, уміння працювати з довідковою, науковою, публіцистичною літературою стають невід'ємними компонентами інформаційної культури майбутнього фахівця.

У спеціальних дослідженнях обгрунтовуються загальнометодологічні принципи організації сучасної інформаційної освіти, зокрема йдеться про принципи 
культурологічного підходу, системного підходу, інтегративності, діяльнісного підходу, технологічного підходу, неперервності (Гендіна, 1999: 35). Слід зазначити, що інформаційна культура майбутнього фахівця не може бути сформована в результаті лише механічного поєднання знань та умінь $з$ урахуванням означених компонентів. Тільки органічне поєднання всіх цих компонентів може забезпечити результативність даного процесу.

Формування інформаційної культури майбутніх фахівців інформаційної сфери - це доволі складний процес, пов'язаний 3 вирішенням цілої низки завдань практичного характеру, зокрема таких, як розвиток уміння особистості здійснювати інформаційну діяльність, набуття специфічних умінь та навичок засвоєння методів аналітико-синтетичної переробки інформації, набуття інформаційно-комунікативної компетентності тощо.

Для успішної реалізації цих завдань мають бути створені відповідні організаційно-педагогічні умови. Найбільш важливими умовами формування інформаційної культури майбутніх фахівців інформаційної сфери ми вважаємо наступні:

- забезпечення цілісності й системності формування інформаційної культури студентів;

- побудова змісту i структури навчально-виховного процесу відповідно до завдань і основних компонентів інформаційної культури;

- поєднання в процесі навчання різних джерел інформації;

- залучення студентів до інтенсивної інформаційної діяльності, набуття навичок створення професійно значущих інформаційних продуктів;

- організація у закладі вищої освіти інформаційного середовища, включно 3 інформаційними ресурсами навчального закладу, яке стимулювало би до творчої інформаційної діяльності;

- підвищення рівня інформаційної культури педагогів і тих, хто навчається; 
- налагодження взаємодії системи освіти з різноманітними інформаційними установами та використання їх ресурсів в навчальному процесі.

Нарешті, важливою умовою успішної постановки проблеми формування інформаційної культури студентів та реалізації їі в процесі професійної підготовки майбутніх інформаційників є дотримання всіх загально-дидактичних принципів: науковості, доступності, активності, наочності, диференціації та індивідуалізації навчання, зв'язку навчання 3 практикою (Коломієць, 2019:158).

В умовах розвитку інформаційного суспільства виникає необхідність широкого впровадження інноваційних підходів до змісту та організації навчання в умовах професійної освіти. Тому маємо визнати важливість активного застосування засобів інформаційних технологій у професійній підготовці майбутніх фахівців інформаційної сфери. Вони можуть відігравати роль засобів забезпечення процесу формування інформаційної культури, оскільки виконують функції джерел інформації, наочних посібників, індивідуального інформаційного простору, засобу діагностики і контролю. Вони є робочим інструментом майбутнього фахівця, а саме: засобом підготовки документів та їх зберігання, засобом моделювання тощо. Їх використовують також й для створення нових програмних продуктів.

До таких засобів слід віднести електронний підручник, мультимедійну систему, банк даних, експертну систему, електронний бібліотечний каталог, локальні та розподільчі (глобальні) обчислювальні системи, електронну пошту, голосову електронну пошту, електронну дошку оголошень, систему телеконференцій, автоматизовану систему організаційного управління, автоматизовану систему управління науковими дослідженнями тощо.

Основним засобом інформаційних технологій нині $€$ комп'ютер із відповідним програмним забезпеченням. Він здатний виконувати всі процедури зі збору, передачі та обробки 
інформації, які притаманні засобам інформаційних технологій навчання. Серед його можливостей виділяємо наступні: збереження вихідної інформації для повторного опрацювання; використання різних типів джерел інформації; можливість одночасного паралельного опрацювання; можливість накопичувати результати та переходити на новий рівень якості; висока екологічність; особливі вимоги до представлення результатів взаємодії техніки та людини; широкий спектр користувачів; системи опрацювання інформації в режимі реального часу.

Отже, використання інформаційних ресурсів у системі професійної підготовки майбутніх інформаційників впливає на якість освітніх послуг й має забезпечити конкурентоспроможність випускників за рахунок інформатизації всіх форм освітньої діяльності. Ефективність використання інформаційних ресурсів у здійсненні цієї підготовки залежить від рівня ії методичного забезпечення.

Методичне забезпечення розглядають як цілісну систему дій і заходів, спрямовану на продукування нових педагогічних ідей і технологій навчання, вироблення позицій щодо важливих педагогічних проблем, виявлення й узагальнення найкращого педагогічного досвіду.

Інформаційні освітні ресурси уможливлюють змістове наповнення освітнього простору та забезпечують рівний доступ учасників навчально-виховного процесу до якісних навчальних та методичних матеріалів незалежно від місця проживання і форми навчання. Під інформаційними освітніми ресурсами ми розуміємо навчальні, наукові, інформаційні, довідкові матеріали та засоби, розроблені в електронній формі. Вони мають бути представлені на носіях будь-якого типу або розміщені у комп'ютерних мережах, які відтворюються за допомогою електронних цифрових технічних засобів.

Інформаційні освітні ресурси вважаються одним 3 головних елементів інформаційно-освітнього середовища. За функціональною ознакою їх можна класифікувати як: 
- навчально-методичні (навчальні плани, робочі програми навчальних дисциплін, розроблені відповідно до навчальних планів);

- методичні (тематичні плани, методичні посібники, методичні вказівки для вивчення окремого курсу та керівництва 3 виконання проектних робіт);

- навчальні (електронні підручники та навчальні посібники);

- допоміжні (збірники документів і матеріалів, довідники, покажчики наукової та навчальної літератури, наукові публікації, матеріали конференцій, електронні довідники, словники, енциклопедії);

- контрольного характеру (тестові програми, контрольні питання і завдання з навчальних дисциплін).

У системі сучасної освіти активно використовуються освітні веб-ресурси. Це ті інформаційні ресурси, які розміщені у веб-просторі локальної чи глобальної мережі у вигляді різних форматів (текстового, графічного. архівного і т. д.). Особливої уваги в освітніх веб-ресурсах заслуговують вікі-сайти. Їх використання відкриває широкі можливості для навчальної діяльності, зокрема для реалізації свободи у навчанні, для самостійного засвоєння і накопичення знань.

Найбільш успішними інформаційними проектами методичної системи в сфері освіти є: український портал osvita.ua, вікі-сайт http://uk.wikipedia.org/wiki. Блок нормативно-правового забезпечення представлений Верховною Радою України (rada.gov.ua), Міністерством освіти і науки України (www.mon.gov.ua), Урядовим порталом (kmu.gov.ua), освітянською мережею України (www.ednu.kiev.ua). Блок джерел наукової і педагогічної інформації презентують Національна бібліотека України ім. В. Вернадського (www.nbuv.gov.ua), Національна парламентська бібліотека (www.nplu.kiev.ua), Міжнародна відкрита науково-практична конференція «Теорія і практика дистанційного навчання в освіті» (https://cutt.ly/HhTSUjN). 
Зазначимо також, що використання інформаційних ресурсів в процесі професійної підготовки фахівців інформаційної сфери потребує відповідної інформаційної компетентності, належного рівня інформаційної культури педагогічних працівників, задіяних в цьому процесі. Інформаційна культура науково-педагогічних працівників змістовно охоплює інформативну компетентність, ціннісні орієнтації, мотиви діяльності в інформаційному середовищі, механізми соціокультурної регуляції. У ¥ї структурі слід виділити наступні компоненти:

- культура організації подання інформації;

- культура сприймання інформації;

- культура використання інформації;

- культура спілкування в інформаційному середовищі.

Висновки та перспективи подальших досліджень. Отже, удосконалення системи професійної підготовки фахівців інформаційної сфери є важливим завданням сьогодення. Нині здійснюється пошук ефективних інноваційних моделей підготовки майбутніх інформаційників, інформаційних аналітиків, бібліотекознавців, архівознавців, здатних до комплексної діяльності, спрямованої на формування i використання інформаційних ресурсів, створення інформаційної продукції, надання інформаційних послуг, інформаційного супроводу та підтримки всіх видів діяльності.

Перспективними в подальшому дослідженні цієї проблеми вважаємо вдосконалення методології і стратегії відбору змісту, методів і організаційних форм навчальновиховного процесу, що відповідатимуть завданням розвитку майбутнього фахівця в сучасних умовах.

\section{ДЖЕРЕЛА ТА ЛІТЕРАТУРА}

1. Антоненко I. Є. Кваліфікаційні вимоги до фахівців у сфері керування документаційними процесами (досвід Австраліі). Бібліотекознавство. Документознавство. Інформологія. 2006. № 3. С.61-65. 
2. Антонченко М. А. Інформаційна культура як складова загальнолюдської культури. Науковий часопис НПУ імені М. П. Драгоманова. Серія №2. Комп'ютерно-орієнтовані системи навчання: зб. наукових праць. Київ, НПУ імені М. П. Драгоманова. 2004. № 1 (8). С.161-166.

3. Баловсяк Н. Інформаційна компетентність фахівця. Педагогіка і психологія професійної освіти. Київ, 2004. № 5. C. 21-28.

4. Барма О. Формування інформаційної культури студентівменеджерів у рамках діяльності бібліотек вищих навчальних закладів (на прикладі бібліотеки Білоруського державного університету культури та мистецтв). Вісник Львіського ун-ту. Серія книгозн. бібліот. та інф. технол. 2014. Вип.9. С. 254-263.

5. Бездрабко В. В. Підготовка наукових кадрів із документознавства в Україні: модерні відповіді на виклик часу. Наукові записки Національний університет «Острозька академія». Острог, 2009. Вип.1. С.241-254.

6. Власова Г. В., Титова О. В., Шмегера О. В. Дидактичні основи комп'ютерної підготовки фахівців із спеціальності «Документознавство та інформаційна діяльність». Документознавство та інформаційна діяльність: наука, освіта, практика: зб. матеріалів наук. конф. (Київ, 18 грудня 2002 р.) / Держ. акад. кер. кадрів культури і мистець. Київ, 2002. C.81-85.

7. Вохрышева М. Г. Информационная культура в системе культурологического образования специалиста. Проблемы информационной культуры: сб. науч. ст. Самара: СГАКИ, 1994. C. 7-28.

8. Вохрышева М. Г. Формирование науки об информационной культуре. Проблемь информациионой культурыл. Магнитогорск, 1997. Вып. 6. Методология и организация информационно-культурологических исследований. С. 48-63.

9. Гендина Н. И. Информационная культура, творчество и креативность выпускника высшей школы в контексте проблем 
развития человеческого капитала информационного общества (ч.2). URL: https://cutt.ly/4hLFqV1

10. Гендина Н. И. Основы информационной культуры Основы информационной культуры: сб. метод. материалов. Кемерово, 1999. С. 35.

11. Зиновьева Н. Информационная культура личности: введение в курс: учеб пособие для вузов культуры и искусства. Краснодар. Гос. акад. Культуры, 1996. 136 с.

12. Коломієць О. Б. Педагогічні умови формування інформаційної культури майбутнього документознавия в умовах сьогодення: матеріали Всеукраїнської науковопрактичної інтернет-конференції «Вітчизняна наука на зламі епох: проблеми та перспективи розвитку». ПереяславХмельницький, 2019. Вип. 54. С.155-159.

13. Кулешов С. Г., Прокопенко I. П. Управління документацією: підготовка фахівців у вищих школах за рубежем. Архіви Украӥни. 2003. № 1-3(251). С.53-64.

14. Левшин М. Педагогічна сутність поняття «інформаційна культура» особистості». Вища освіта України. 2002. №3. C.67-74.

15. Матвієнко О.В.Досвід підготовки інформаційних спеціалістів в зарубіжних країнах. Рідна шк.. 2001. № 10. С.76-77.

16. Медведева О. Основы информационной культуры. Социологические исследования. 1994. № 11. С. 59.

17. Семенюк Е. А. Інформаційна культура суспільства i прогрес інформатики. НTI. Сер.1. 1994. №7. С.3.

18. Філіпова Л. Я. Інтернет-технології в системі підготовки фахівців зі спеціальності «Документознавство та інформаційна діяльність». Інформаційні технологї $i$ системи в документознавчій сфері: матеріали між нар. наук.-прак. конф. (м. Донецьк, 30 берез. 1 квіт. 2011 р.). Донецьк, 2011. C. 141-143.

19. Філіпова Л. Я. Нова наукова проблематика спеціальності «Документознавство, архівознавство»: вимоги часу. 
Документознавство. Біліотекознавство. Інформаційна діяльність: проблеми науки, освіти, практики: матеріали $\mathrm{V}$ міжнар. наук.-практ. конф. (Київ, 20-22 трав. 2008 р.) Київ, 2008. C.83-85.

20. Філіпова Л. Я. Перспективна спеціальність у підготовці фахівців інформаційно-документної сфери. Вісн. Книжк. палати. 2003. № 10.

\section{REFERENCES}

1. Antonenko, I. (2006). Kvalifikatsiini vymohy do fakhivtsiv u sferi keruvannia dokumentatsii nymy protsesamy (dosvid Avstralii) [Qualification requirements for specialists in the field of documentation process management (Australian experience)]. Bibliotekoznavstvo. Dokumentoznavstvo. Informolohiia. 61-65 [in Ukrainian].

2. Antonchenko, M. (2004). Informatsiina kultura yak skladova zahalnoliudskoi kultury [Information culture as a component of universal culture]. Naukovyi chasopys NPU imeni M.P. Drahomanova. Kyiv. NPU imeni M. P. Drahomanova, 1 (8). 161-166 [in Ukrainian].

3. Balovsiak, N. (2004). Informatsiina kompetentnist fakhivtsia [Information competence of the specialist]. Pedahohika $i$ psykholohiia profesiinoi osvity, 5. 21-28 [in Ukrainian].

4. Barma, O. (2014). Formuvannia informatsiinoi kultury studentiv-menedzheriv u raskakh diialnosti bibliotek vyshchykh navchalnykh zakladiv (na prykladi biblioteky Biloruskoho derzhavnoho universytetu kultury ta mystetstv). [Formation of information culture of students-managers in the activities of libraries of higher educational institutions (on the example of the library of the Belarusian State University of Culture and Arts)]. Visnyk Lviskoho un-tu. Seriia knyhozn. bibliot. ta inf. tekhnol, 9. 254-263 [in Ukrainian].

5. Bezdrabko, V. (2009). Pidhotovka naukovykh kadriv iz dokumentoznavstva $\mathrm{v}$ Ukraini: moderni vidpovidi na vyklyk chasu [Training of scientific personnel in document science in Ukraine: 
modern answers to the challenge of time]. Naukovi zapysky. Ostroh, 241-254[in Ukrainian].

6. Vlasova, H. (2002). Dydaktychni osnovy kompiuternoi pidhotovky fakhivtsiv iz spetsialnosti «Dokumentoznavstvo ta informatsiina diialnist» [Didactic bases of computer training of specialists in the specialty «Documentation and information activities»]. Dokumentoznavstvo ta informatsiina diialnist: nauka, osvita, praktyka: zb. materialiv nauk. konf. (Kyiv, 18 hrudnia 2002 r.) Kyiv. 7. 81-85 [in Ukrainian].

7. Vokhrysheva, M. (1994). Informaczionnaya kultura v sisteme kulturologicheskogo obrazovaniya speczialista [Information culture in the system of culturological education of a specialist]. Problems of information culture: Sat. articles Samara: SHAKY, 1994. 7-28 [in Russian].

8. Vokhrysheva, M. (1997). Formirovanie nauki ob informaczionnoj kulture [Formation of the science of information culture]. Problems of information culture: Sat. Art. M, Magnitogorsk. 6.48-63[in Russian].

9. Gendina, N. Informaczionnaya kultura, tvorchestvo i kreativnost vypusknika vysshej shkoly $\mathrm{v}$ kontekste problem razvitiya chelovecheskogo kapitala informaczionnogo obshhestva (ch.2) [Information culture, creativity and creativity of a graduate of higher education in the context of problems of development of human capital of the information society]. Retrieved from https://cutt.ly/OhTSFeQ

10. Hendyna, N. (1999). Osnovy informatsyonnoy kultury [Fundamentals of information culture]. Osnovy informatsyonnoi kultury: sb. metod. materyalov. Kemerovo.35 [in Russian].

11. Zinovieva, N. (1996). Informaczionnaya kultura lichnosti: vvedenie v kurs: ucheb posobie dlya vuzov kultury i iskusstva [Information culture of personality: an introduction to the course: a textbook for universities of culture and art]. Krasnodar.136 [in Russian].

12. Kolomiiets O. B. Pedahohichni umovy formuvannia informatsiinoi kultury maibutnoho dokumentoznavtsia $\mathrm{v}$ umovakh 
sohodennia [Pedagogical conditions for the formation of information culture of the future documentologist in today's conditions]. Materialy Vseukrainskoi naukovo-praktychnoi internetkonferentsii «Vitchyzniana nauka na zlami epokh: problemy ta perspektyvy rozvytku»: Zb. nauk. prats. Pereyaslav-Khmelnytsky, 54.155-159 [in Ukrainian].

13. Kuleshov, S. (2003). Upravlinnia dokumentatsiieiu: pidhotovka fakhivtsiv u vyshchykh shkolakh za rubezhem [Management of documentation: training of specialists in higher schools abroad]. Arkhivy Ukrainy, 1-3 (251). 53-64 [in Ukrainian].

14. Levshyn, M. (2002). Pedahohichna sutnist poniattia «informatsiina kultura» osobystosti» [Pedagogical essence of the concept of «information culture» of the individual]. Vyshcha osvita Ukrainy, 3. 67-74 [in Ukrainian].

15. Matviienko, O. (2001). Dosvid pidhotovky informatsiinykh spetsialistiv $\mathrm{v}$ zarubizhnykh krainakh [Experience in training information specialists in foreign countries]. Ridna shk. 10. 76-77 [in Ukrainian].

16. Medvedeva, O. (1994). Osnovy informaczionnoj kultury [ Fundamentals of information culture]. Sociological research. 11. 59 [in Russian].

17. Semeniuk, E. (1994). Informatsiina kultura suspilstva i prohres informatyky [Information culture of society and the progress of informatics]. NTI. 7(1).3 [in Ukrainian].

18. Filipova, L. (2011). Internet-tekhnolohii v systemi pidhotovky fakhivtsiv zi spetsialnosti «Dokumentoznavstvo ta informatsiina diialnist» [Internet technologies in the system of training specialists in the specialty "Documentation and information activities»]. Informatsiini tekhnolohii $i$ systemy $v$ dokumentoznavchii sferi: materialy mizh nar. nauk.-prak. konf. Donetsk.141-143 [in Ukrainian].

19. Filipova, L. (2008). Nova naukova problematyka spetsialnosti «Dokumentoznavstvo, arkhivoznavstvo»: vymohy chasu [New scientific problems of the specialty «Documentation, archival science»: the requirements of the time]. Dokumentoznavstvo. 
Biliotekoznavstvo. Informatsiina diialnist: problemy nauky, osvity, praktyky: materialy V Mizhnar. nauk.-prakt. konf. (Kyiv, 20-22 trav. 2008 r.) Kyiv.83-85 [in Ukrainian].

20. Filipova, L. (2003). Perspektyvna spetsialnist u pidhotovtsi fakhivtsiv informatsiino-dokumentnoi sfery [Promising specialty in the training of specialists in the information and documentary field]. Visn. Knyzhk. Palaty. 10. 29-31 [in Ukrainian].

\section{АНОТАЦІЯ}

Публікачія присвячена проблемі формування інформаційної культури майбутнього фахівия інформаційної сфери.

Розглянуто поняття «інформаџійна культура», передумови виникнення інформаційної культури в суспільстві, їі основні компоненти та рівні функціонування.

Інформачійна культура розглядається як спосіб життедіяльності людини в інформаційному суспільстві, складова процесу формування культури людства, як культура людини, готової до творчої роботи в умовах технологоінформаційної системи розвитку суспільства.

Така дефініція інформаційної культури дозволяє системно розглядати основні проблеми і напрямки розвитку інформаційної культури, адекватно визначати об'єкт $i$ предмет ї̈ дослідження, а також провести структуризацію іï предметної сфери.

Проаналізовано інформаційну культуру особистості як умову успішної адаптації людини до життя в інформаџійному суспільстві, як складову загальної культури, щуо орієнтована на інформаційне забезпечення людської діяльності.

Формування інформачійної культури майбутнього інформаційника представлено як складний процес, щзо має включати освітні ресурси загальної культури суспільства, потенціал навчально-виховного і сочіокультурного середовища закладу вищої освіти, духовний саморозвиток особистості студента. При ц̧ьому зазначено, щуо формування інформащійної 
культури тільки через вивчення інформатики виявляється недостатнім, оскільки обмежує изей процес технічними та програмними засобами інформатизаияії.

Обгрунтовується доиільність впровадження 6 навчальний прочес спеціальних навчальних курсів, зокрема, «Основи інформаційної культури особистості» або «Інформаційна культура майбутнього фахівияя».

Схарактеризовано організаційно-педагогічні умови успішного здійснення прочесу формування інформаџійної культури майбутнього фахівия. Підкреслено важливість активного застосування засобів інформаційних технологій у професійній підготовці майбутніх фахівців інформаційної cфрерu.

У висновках наголошено, щуо нині здійснюється пошук ефективних інноваційних моделей підготовки майбутніх інформаційників, здатних до комплексной діяльності, спрямованої на формування $і$ використання інформаційних ресурсів, створення інформачійної продукцї, надання інформаційних послуг, інформачійного супроводу та підтримки всіх видів діяльності. Визначено перспективні напрями в подальшому дослідженні иієї проблеми.

Ключові слова: інформація, інформаційне суспільство, інформатизація, інформаційна культура, інформаційні технологї, фахівецьь інформаційної справи.

\section{АННОТАЦИЯ}

Публикачия посвящена проблеме формирования информационной культуры будущуего спецчиалиста информационной сферь.

Рассмотрено понятие «информационная культура», предпосылки возникновения информационной культуры в обществе, ее основные компоненть и уровни функиионирования.

Информачиионная культура рассматривается как способ жизнедеятельности человека в информационном обществе, 
составляюшцая прочесса формирования культуры человечества, как культура человека, готового к творческой работе в условиях технолого-информационной системы развития общества.

Такая дефиниция информационной культуры позволяет системно рассматривать основные проблемы и направления развития информационной культуры, адекватно определять объект и предмет ее исследования, а также провести структуризацию ее предметной области.

Проанализирована информационная культура личности, которая является условием успешной адаптации человека к жизни в информационном обществе, составляющей общей культуры, ориентированной на информационное обеспечение человеческой деятельности.

Формирование информациионой культуры будущеего специиалиста информационной сферы представлено как сложный прочесс, включающий образовательные ресурсы общей культуры общзества, потенциал учебновоспитательной и сочиокультурной среды высшего учебного заведения, духовное саморазвитие личности студента. При этом подчеркивается, что формирование информационной культуры только посредством изучения информатики является недостаточным, поскольку ограничивает этот проиеес техническими и программными средствами информатизацчии.

Обосновывается иелесообразность включения в учебный прочесс специальных учебных курсов, в частности, «Oсновы информационной культуры» или «Информационная культура будущуего специиалиста».

Дана характеристика организационно-педагогических условий успешного осущзествления процесса формирования информационной культуры будущуего специалиста. Подчеркнута важность активного использования при этом средств информачионных технологий.

В заключении акцентируется внимание на поиске 
эффрективных инновационных моделей подготовки будущзих специиалистов информационной сферы, способных $к$ комплексной деятельности, направленной на формирование и использование информационных ресурсов, создание информационной продукции, предоставление информационных услуг, информационного сопровождения и поддержки всех видов деятельности. Определены перспективные направления в дальнейшем исследовании этой проблемь.

Ключевые слова: информачия, информациионое общество, информатизация, информационная культура, информационные технологии, специалист информационной сферь. 